could not possibly be identical--is now exploded and can never be revived again. Both Professor Virchow and Mr. Burnouf have accepted Dr.Schliemann's theory that the immense bed of the small and insignificant rivulet Kalifatli-Asmak, which has no running water except during the inundations in winter-that this riverbed, which has in many places a breadth of from $660 \mathrm{ft}$. to $825 \mathrm{ft}$. -is identical with the ancient bed of the Scamander.

Dr. Schliemann then describes the results of his excavations on the gigantic tumuli called Udjek-Tepé anł Besika-Tepé. He now inclines more and more to the conviction that these and other immense Trojan tumuli were no real tombs, but mere memorials erected in commemoration of some great event. "They certainly existed at the time of Homer, who mentions four of them (those of Batieia, Assyetes, Ilus, and Achilles) as real tombs, no doubt because, in his time, similar conical tumuli were erected at Sardis and elsewhere on the Asiatic coast over the ashes of great men."

In continuing his excavations at Troy, Dr. Schliemann found two other treasures of Trojan gold jewellery, and Ilium, he states, appears now exhausted. Dr. Virchow and M. Burnouf are astonished at the monstrous quantity of bricks, which solely occur in the burnt city. The three explorers are convinced that these bricks must have been slightly burnt in" an oven before being used for building.

Mr. Sayce, in a letter in yesterday's Times, states that the markings on a fragment of pottery, a fac-simile of which was sent him by Dr. Schliemann, are rude attempts to imitate cuneiform characters on the part of a potter who was unacquainted with the meaning of the latter. "As is well known, the specimens of Phønician art found in the Mediterranean frequently bear rude representations of Egyptian hieroglyphics figured for the sake of ornament, and grouped in such a way as to show that the artist had not the faintest idea of their signification. If $m y$ view of the markings on the piece of pottery discovered by Dr. Schliemann is correct, it becomes certain that some kind of prehistoric intercourse was carried on between the Troad and the populations who employed the cuneiform system of writing, and since the remains found at Hissarlik show little or no trace of Assyrian or Phœenician influence, the intercourse must be assigned to the older Babylonian period. Five years ago I suggested that some of the designs on the terra-cotta disks from Hissarlik might be rude imitations of designs on archaic Babylonian cylinders. I may add that $\mathrm{Mr}$. Newton, to whom I showed the fac-simile sent me by Dr. Schliemann, thought my view of it very possibly right."

In connection with the above the Times states that a recent number of the Norddeutsche Zitung stated that the Chinese Ambassador at Berlin, Li Fangpao, well known in his own country as a great scholar, has lately read as Chinese the inscription on a vase found by Dr. Schliemann in the lowest stratum of his excavations at Hissarlik, and figured on p. 50 of the introduction to his "Troy and Its Remains." Li Fangpao is quite confident that the unknown characters, which recur again and again on the Trojan antiquities, especially on the terra-cotta whorls, are those of his native tongue, and gives as the purport of the inscription, that about B.C. I200, three pieces of linen gauze were packed in the vase for inspection.

With reference to this Mr. Sayce states that the authority of the Chinese ambassador, high as it is, -will never persuade any one acquainted with the characters of the Cypriote syllabary that the characters found on some of the objects from Hissarlik are Chinese. As was stated in a Times leader, they belong, Mr. Sayce repeats, to the curious syllabary which seems to have been used on the coasts of Asia Minor and in the islands of the $\mathbb{E}$ gean before the introduction of the simpler Phœnician alphabet, and which continued to be employed in conservative Cyprus down to a late date.

\section{ON THE ORIGIN OF THE SOLAR PROTUBERANCES}

$W \mathrm{~W}$ take the following from a communication made by Herx Sporrer to the Berlin Academy on November 7 :-

"Simultaneously with the minimum of sun-spots the protuberances have been also insignificant hitherto, but since the middle of this year (1878), while the spot minimum continues to last even far beyond expectation, important protuberances have yet appeared, and among them some from which important deductions may be drawn with tolerable certainty.

"According to my observations of the year 1871 I had distin. guished two classes of protuberances, viz., the ordinary hydrogen protuberances, and the flame-like protuberances which are remarkable on account of their intensity and pointed forms. In the latter ones, apart from the $\mathrm{H}$ lines and $\mathrm{D}_{3}$, the magnesium lines may be easily recognised even with the smaller 5 -inch telescope, which was then and is now at my disposal; other lines are less easily recognised. When Secchi agreed with me in this division of protuberances he chose the name of 'metallic' ones for the second kind, because the lines of metallic elements principally appear in them, apart from the $H$ lines and $D_{3}$.

"No doubt we may suppose that many of the ordinary hydrogen protuberances originate through storms forcing up the hydrogen sea in gigantic vhirls and waves, and $I$ have also succeeded in finding examples confirming this, as the changes observed took place entirely after the manner corresponding to our waterspouts; this, however, does not exclude that many of the hydrogen protuberances originate through eruptions from the interior of the sun's body. We are still more inclined to look upon the flame-like protuberances as eruption products, I had considered also whether for the explanation of these, electricity might not be taken into account, particularly since then the quick shooting up and the quick change of the formations would not have to be explained merely by the motion of masses, and the over-great velocity would not be so surprising. Indeed, observed zigzag lines of communication between neighbouring flame-like protuberances had suggested the thought of electric discharges.

"The thought that bright protuberances do not start from the curface, nor yet from the hydrogen envelope, but rather that they are formed only at a certain height, therefore that perhaps at the low temperature existing at greater heights, chemical combinations take place, and that only by these the intense flaring up is produced-this thought may doubtless not be designated as a new one, but no forms of protuberances have been published yet which would decidedly favour this view."

Herr Spörer then quotes from numerous Italian publications a considerable number of protuberances which appeared perfectly detached from the surface, and says he could considerably augment these examples from his own observations. But the objection may be made to these cases that the formations described are only the remains of larger ones which previousiy had their origin at the sun's surface. This objection is perfectly justified since observations have proved often enough that brightly luminous protuberances became partly obscured, and particularly that the foot of a protuberance disappeared while the upper part remained visible.

It is necessary therefore to adduce such examples where the proof may be furnished with certainty that a luminous formation which is observed detached from the surface, did not originate at the sun's surface. Now Herr Spörer together with Herr Kempf has observed protuberances of this nature in July and August last year; he deferred their publication in the hope of being able to obtain more examples; this hope was annihilated for the present through the beginning of the unfavourable season, and hence the observations which had been made were made known. There were altogether three observations of this lind, which Herr Spörer describes and represents by illustrations; here we must confine ourselves to reproduce the one case which was the most favourable one to his theory, and which was observed on July 22 from 5 h. $30 \mathrm{~m}$. until $6 \mathrm{~h}$. $50 \mathrm{om}$.

The protuberance appeared in lat. $35^{\circ}-40^{\circ}$ south, and attained a height of $46^{\prime \prime}$, or 34,000 kilometres. First of all it was seen in one point in the shape of an eruption, which, by the action of storms, was partly deviated to the left. In this direction an arc appeared, which expanded further to the left (possibly always in consequence of storms), until later on it touched the sun's surface, and thus spanned a dark segment. Intensely bright rays were remarkable about $5 \mathrm{~h} .47 \mathrm{~m}$. when they first appeared, and which proceeded from the highest part of the arc segment in a vertical direction, and quite detached from the solar surface. The direction of the rays did not permit the idea that they might have been torn off from the protuberance on the right by the action of storms perhaps, or otherwise. Then a larger mass was formed by these rays, whereupon extremely quick and varied changes took place, the exact observation of which was impossible, since the slit of the spectroscope could not be widened and therefore only a part of the protuberances could be observed at a time. At $6 \mathrm{~h}$. I2m. the complete arc was seen, the denser part over the middle had become a little looser, but glistening points were again present, standing perpendicular upon the arc; the formation had assumed larger dimensions at $6 \mathrm{~h}$. 
$23 \mathrm{~m}$. To the right a new ray had formed, which attained a much greater height than the other parts of the protuberance, viz., to $6 \mathrm{I}^{\prime \prime}$, or 46,000 kilometres, and which lasted only for a short time.

It might perhaps be thought possible that the vertical rays over the middle of the segment and the larger protuberances originating there, had yet been in connection with the sun's surface, the dark segment having formed the foreground, so that dark and dense gases of this segment might have hidden the parts behind them from view. But then the segment ought to have appeared as a sun spot later on, if it had not happened to appear at the very extreme limb. On account of the enormous dimensions a spot of this kind could not have disappeared entirely until the following day, on July 23, therefore, at least some remains should have been observed really as a spot. But there were not any spots on the sun's disk neither on July 23 nor on the following days, except two small spots on the northern hemisphere on July 26. At the same time we might remark that in the high southern latitude of the protuberance so large a spot has never appeared before; this we know by experience.

The examples of July 24 and of August 9 are equally important, if indeed less grand in proportions. In both cases the protuberance, seen detached from the solar surface, could not be due to the action of storms, but, like the one described above, rather appeared to favour the hypothesis of the origin in higher regions.

\section{UNIVERSITY AND EDUCATIONAL \\ INTELLIGENCE}

THE Cambridge Museums and Lecture Rooms Syndicate have issued their thirteenth annual report, in which they give details of the progress made in the buildings in course of construction. They report that they have no hope that the necessary expenditure upon the various departments of the museums can again be brought within the limits of the existing allowance for their maintenance. Having regard to the present state of the University finances, they have directed a curtailment of expenditure in all directions. This economy, however, although unavoidable at present, will, if persisted in, lower the standard of scientific education in the University, for it will be impossible to maintain the departments in their present state of efficiency. They hope that at no distant date the University will be in a position to increase the fund to a sum sufficient for their proper maintenance on the enlarged scale rendered necessary by the erection of the new buildings and the increased number of students. Appended to the report are the reports of the various professors, the superintendent of the Museums of Zoology and Comparative Anatomy, the Strickland Curator, and the Trinity Prælector of Physiology on the conditions of their several departments.

A MEETING of the curators of the University of Edinburgh was held on Friday, the 6th inst., with reference to the vacancy in the Chair of Mathematics caused by the death of Prof. Kelland, and it was resolved to hold another meeting early next month as to the appointment of a successor. Meantime, it is requested that the applications of intending candidates, accompanied by any testimonials desired to be submitted, be forwarded by Saturday, July 5. The emoluments, which are derived from a fixed endowment and from class fees, amount to between I, 200l. and 1,500l. per annum. Any details desired can be obtained from the Secretary to the Senatus Academicus.

The ninth Annual Report of the Wellington College Natura History Society has to record a good deal of satisfactory work done, as is evident, indeed, from the very full lists and reports appended in the various departments. We should like to see the recommendation adopted given to those Fellows who do not play cricket, that they should devote themselves in the afternoons to the observations of birds and insects. A very fair proportion of the members, however, seem to do wurk.

THE new university building of Marburg was inangurated on May 29 in the presence of Dr. Falk, the German "Cultusminister."

\section{SOCIETIES AND ACADEMIES LONDON}

Royal Society, May 15.- "On the Capillary Phenomena of Jets," by Lord Rayleigh.

In this paper are given the results of observations and their discussion on water issuing under varying pressure from orifices of various shapes.
Geological Society, May 28.-Henry Clifton Sorby, F.R.S., president, in the chair.-Edward Garlick was proposed as a Fellow of the Society.-The following communications were read :- On the endothiodont reptilia, with evidence of the species Endothiodon uniseries, Owen, by Prof. R. Owen, C.B., F.R.S. The author referred to the characters assigned by him to his Endothiodon bathystoma, which had the alveolar borders of both jaws toothless, perhaps covered with horn during life, as in the Chelonians; whilst within this border there were three series of teeth both in the palate and the mandible. He next described a new species, under the name of Endothiodon uniseries, founded upon the fore-half of a skull, having only a single row of teeth in the palate, a character which may prove to be of generic importance. The author finally discussed the relationships of this genus, which he regarded as belonging to the order Anomodontia, and as showing, like Oudenodon, traces of derivation from Dicynodon in the presence of caniniform processes in the upper jaw. The development of teeth interior to the alveolar margins in both jaws was to be regarded as a cha. racter of family value, and the author remarked upon the interest of the continuance of a common ichthyic and batrachial dental character in exceptional cases among the reptilia up to the establishment of the crocodilian type, above which, in the vertebrate series, calcified palatal teeth no longer appear. -Note (third) on Eucamerotus, Hulke, Ornithopsis, Seeley, = Bothriospondylus maonus, Owen, $=$ Chondrosteosaume magnus, Owen, by J. W. Hulke, F.R.S.-Description of the species of the ostracodous genus Bairdia, $\mathrm{M}^{6} \mathrm{Coy}$, from the carboniferous strata of Great Britain, by Prof. T. Rupert Jones, F.R.S., and James W. Kirkby. The long persistence of the genus Bairdia, from the silurian period to the present day, and its essentially marine character, were first noticed; also the relatively rare occurrence of any species of Leperditia, Beyrichia, and Kirkbya (associates of Bairdia in carboniferous strata) in fresh-water or estuarine beds. Carbonia, on the other hand, was confined to the fresh or brackish waters in which the coal-measures were formed. The difficulty of defining the species of Bairdia from carapace-valves alone, without limbs and soft parts, and the possibility of several genera being grouped under this head, were mentioned. The species of Bairdia described and figured in this paper were, it is believed, all that have been found in the British carboniferous rocks, with the exception of M'Coy's $B$. gracilis. Two of Count Muinster's Bavarian Bairdice, from Hof, bave not yet occurred with us; neither have four of Dr, d'Eichwald's Russian carboniferous species, nor the Australian B. affinis, Morris. Including these, there are twenty-three known carboniferous species of Bairdia. Seven of these are recurrent in the overlying permian limestones, which have yielded twelve species of this genus. With six silurian forms, there are altogether thirtyfour recorded palæozoic species of Bairdia.-Report on a collection of fossils from the Bowen River coal-field and the limestone of the Fanning River, North Queensland, by R. Etheridge, jun., F.G.S.-On a fossil Squilla from the London clay of Highgate, part of the Wetherell collection in the British Museum, by $\mathrm{H}$. Woodward, F.R.S.-On Necroscilla Wilsoni, a supposed stomatopod crustacean from the middle coal-measures, Cossall, near Ilkeston, Derbyshire, by H. Woodward, F.R.S.-On the discovery of a fossil Squilla in the cretaceous deposits of Hâkel, in the Lebanon, by H. Woodward, F.R.S.-On the occurrence of a fossil king-crab (Limulus) in the cretaceous formation of the Lebanon, by H. Woodward, F.R.S.

Zoological Society, June 3.--Prof. W. H. Flower, LL.D., F.R.S., president, in the chair.-The Secretary exhibited and made remarks upon two volumes of original drawings of the birds of India, which had been deposited in the Society's Library by Brigadier-General A. C. McMaster. The volumes contained about 270 figures of the birds of India, most of which had been drawn by soldiers in General McMaster's house at Secunderabad. -Mr. Sclater exhibited and made remarks on a small collection of birds forwarded to him by Dr. A. Döring, of the University of Cordova, in the Argentine Republic.-Mr. W. Ottley gave a description of the blood-vessels of the neck and head of the ground hornbill.-Mr. Edward R. Alston read a paper on the specific identity of the British martens, in which he pointed out the distinguishing characters of Martes sylvatica and M. foina, and showed that the former species only is found in this country. -Messrs. Sclater and Salvin gave an account of the birds collected by the late Mr. T. K. Salmon in the State of Antioquia, United States of Columbia. Mr. Salmon's collections were stated to have been very extensive, having been the product of 